\title{
Complex Sentences in Robert Coover's Chicago Cryptogram : a stylistic Study
}

\author{
https://doi.org/10.32792/utq/utj/vol10/1/4
}

\author{
Mutar Sabeeh Nasir \\ Isa Atallah Salmam
}

\begin{abstract}
Complex sentences are grammatical features used by writers of literature, including short fiction, as means for achieving their themes, portraying their characters and describing their events. This study is an attempt at making an analysis of Robert Coover's stylistically effective uses of complex sentences in his short story Chicago Cryptogram from his collection A Child Again 2005. In other words, this study aims at investigating Coover's individual style of complex sentences. In this study, each complex sentence in the above-mentioned short story is analysed according to the number of clauses it contains. This analysis is based on Leech and Short's analysis model 1981.0

It is concluded that by means of complex sentences, Robert Coover conveys his complex ideas. Subordinate clauses have a higher ratio of clauses than main clauses because the supporting and modifying ideas are more than the principal ones. Also, the most complex sentences are made use of to describe characters and their activities, besides key events in the story.
\end{abstract}

Keywords: complex sentence, stylistic marker, styloanalysis, Robert Coover, modifying and principle ideas.

\section{Introduction}

Complex sentences are grammatical features whose stylistic use in short fiction can be explored as a stylistic marker of a writer. An analysis of sentences according to the number of clauses in them may differentiate one writer from another in terms of complex sentence style. Thus, Turner (1973:71) states that a writer who can be shown to be using many more subordinate clauses containing if, that, although, while can be detected as a writer who uses more complex sentences than another one who often uses one-clause sentences.

This study aims at identifying the role of complex sentences in the selected fictional text and specifying where complex sentences have greater densities of clauses in this text and what functions these densities sense. These views need to be empirically and stylistically assessed to get at Coover's complex sentence style. 


\section{Complex Sentence}

This section discusses the basic grammatical notion of complex sentence so as to get workable procedural definitions of this key term. The definitions in this section are incorporated in the model of analysis especially developed for the purposes of this study.

A complex sentence consists of only one main clause plus one or more subordinate clauses functioning as elements in the sentence (Garcia, 2002: 19) as in:

She telephoned while you were out.

Subordination, as Wright and Hope (1996:140) state, allows sentences to be expanded almost indefinitely with extra clauses and ideas. Subordinate clauses are very often used in grammar to describe a hierarchic structure of clauses within the complex sentence which has at least two clauses: a main clause and (one or more) subordinate clauses. Similarly, Quirk et. al. (1985:987) maintain that a complex sentence consists of two or more clauses, one of which can stand by itself as a complete and meaningful sentence and it is called the main clause. The other is dependent on the main clause, it is called the subordinate clause:

Everyone could see that he was frightened.

In the sentence above, that he was frightened is the subordinate clause, which is embedded in Everyone could see which is the main clause.

Strumph and Douglas (1999: 341) point out that "the main clause expresses the principal idea of the statement," and that "the subordinate clause expresses an enhancing or modifying idea; its role is to support the main clause." The subordinate clause is connected to the main clause by the use of a subordinating conjunction such as as, if, that, etc.

Complex sentences, in general, consist of a number of clauses, these clauses are of various types and have different functions in the sentence. Quirk and Greenbaum (1973:310) classify clauses into three types: finite, non-finite and verbless clauses. A finite clause is that whose verb element is a finite verb phrase. This type includes simple sentences:

John has visited New York.

A non-finite clause is one whose verb element is a non-finite verb:

Having seen the pictures, he ...

A verbless clause is a clause which contains no verb element:

Although always helpful, he...

\section{The Model for Analysis}




\section{University of Thi-Qar Journal Vol.10 No.1 Mar 2015}

Web Site: https://jutq.utq.edu.iq/index.php/main Email: journal@jutq.utq.edu.iq

The stylistic analysis and discussion of the functionality of complex sentences will be based on Leech and Short (1981). Leech and Short (1981:38) define style as the way in which language is used. They adopt that complex sentences are mainly due to subordination as it is the major device for linking ideas together in a complex sentence.

The co-authors maintain that complex sentences are preferable if the aim of the writer is to present a complex structure of ideas. Thus, a complex structure gives and withholds information and subordinate those of extra information. The analytical procedure followed in this study is as follows:

Clause types

Subordinate clause types

main clauses

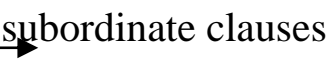

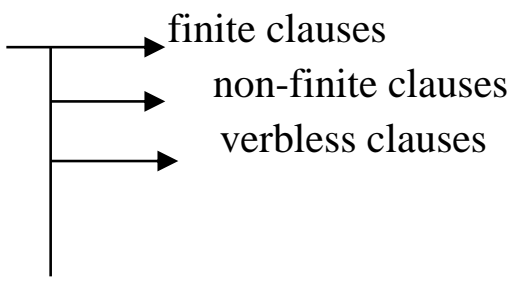

\section{Complex Sentence Styloanalysis and Discussion of the Data}

This section is dedicated to present the procedure of data styloanalysis and discussion by means of counting to explore the possibility of getting at objective inferences based on solid linguistic evidence.

The complex sentences in Chicago Cryptogramare (34). These complex sentences consist in a total of (83) clauses, in which (36) are main clauses comprising (43\%) and (47) are subordinate clauses comprising (57\%) as shown in the table hereunder:

\begin{tabular}{|c|c|c|}
\hline Clause Types & No. & $\%$ \\
\hline Main Clauses & 36 & 43 \\
\hline Subordinate Clauses & 47 & 57 \\
\hline Total & 83 & 100 \\
\hline
\end{tabular}

This table shows that the ratio of subordinate clauses is higher than that of main clauses. This indicates that subordination is used more than coordination in Chicago Cryptogram. Stylistically, this indicates that the modifying ideas are more than the principal ones because most of the principal ideas are not direct and there is a need to introduce them by modifying and supporting ideas. The subordinate clauses fall under the following classification: (27) clauses are finite comprising (57\%), (13) clauses are non-finite comprising (28\%) and 7 clauses are verbless comprising (15\%):

\begin{tabular}{|c|c|c|}
\hline Subordinate Clause Types & No. & $\%$ \\
\hline Finite Clauses & 27 & 57 \\
\hline Non-Finite Clauses & 13 & 28 \\
\hline Verbless Clauses & 7 & 15 \\
\hline Total & 47 & 100 \\
\hline
\end{tabular}




\section{University of Thi-Qar Journal Vol.10 No.1 Mar 2015}

Web Site: https://jutq.utq.edu.iq/index.php/main Email: journal@jutq.utq.edu.iq

It is significant to analyse the density of clauses per sentence to get at Coover's use of clause number per sentence, i.e., such an analysis helps the reader note Coover's accumulation of clauses per sentence which is a result of his complex ideas. The complex sentences are tabulated below according to clause number and type per sentence:

\begin{tabular}{|c|c|c|c|c|c|}
\hline \multirow[t]{2}{*}{ sentence number } & \multirow[t]{2}{*}{ clause number } & \multirow[t]{2}{*}{ main clauses } & \multicolumn{3}{|c|}{ subordinate clauses } \\
\hline & & & finite & non-finite & verbless \\
\hline 1 & 2 & 1 & 0 & 1 & 0 \\
\hline 2 & 2 & 1 & 0 & 1 & 0 \\
\hline 4 & 2 & 1 & 0 & 0 & 1 \\
\hline 5 & 2 & 1 & 1 & 0 & 0 \\
\hline 6 & 2 & 1 & 0 & 1 & 0 \\
\hline 7 & 4 & 2 & 1 & 1 & 0 \\
\hline 8 & 4 & 1 & 3 & 0 & 0 \\
\hline 9 & 3 & 1 & 1 & 1 & 0 \\
\hline 10 & 2 & 1 & 0 & 1 & 0 \\
\hline 12 & 3 & 2 & 0 & 0 & 1 \\
\hline 13 & 2 & 1 & 1 & 0 & 0 \\
\hline 14 & 3 & 1 & 2 & 0 & 0 \\
\hline 15 & 6 & 3 & 3 & 0 & 0 \\
\hline 16 & 2 & 1 & 0 & 0 & 1 \\
\hline 17 & 3 & 1 & 1 & 0 & 1 \\
\hline 18 & 2 & 1 & 1 & 0 & 0 \\
\hline 19 & 2 & 1 & 0 & 0 & 1 \\
\hline 20 & 3 & 1 & 1 & 1 & 0 \\
\hline 21 & 2 & 1 & 1 & 0 & 0 \\
\hline 22 & 5 & 2 & 3 & 0 & 0 \\
\hline 23 & 3 & 1 & 1 & 0 & 1 \\
\hline 24 & 4 & 2 & 0 & 2 & 0 \\
\hline 26 & 2 & 1 & 1 & 0 & 0 \\
\hline 27 & 3 & 1 & 1 & 1 & 0 \\
\hline 29 & 2 & 1 & 1 & 0 & 0 \\
\hline 30 & 2 & 1 & 1 & 0 & 0 \\
\hline 31 & 2 & 1 & 1 & 0 & 0 \\
\hline 32 & 2 & 1 & 1 & 0 & 0 \\
\hline 33 & 3 & 1 & 1 & 0 & 1 \\
\hline 34 & 4 & 1 & 0 & 3 & 0 \\
\hline \multirow[t]{2}{*}{ Total } & \multirow[t]{2}{*}{83} & \multirow[t]{2}{*}{36} & \multicolumn{3}{|c|}{47} \\
\hline & & & 27 & 13 & 7 \\
\hline
\end{tabular}

( NB: sentences Nos. 3,11, 25 and 28 are simple and compound and not part of the analysis.)

The table above provides a verifiable mathematical evidence and observation about Coover's inclination to use multiple clauses per sentence. 


\section{University of Thi-Qar Journal Vol.10 No.1 Mar 2015}

Web Site: https://jutq.utq.edu.iq/index.php/main Email: journal@jutq.utq.edu.iq

To end with, the results of the analysis of this short story show that Coover uses complex ideas widely as the theme of the short story necessitates. The theme which expresses the pain of growing old with deep longing for childhood needs complex sentences to carry Coover's views and thoughts of seeing the world as he belongs to the postmodern movement of the American fiction.Therefore, the profusion of ideas per sentence leads to the abundance of clauses, whether main or subordinate ones. In this case, Coover's style centers on the use of subordinate clauses for holding his modifying and supporting ideas. So, this is Robert Coover's stylistic marker.

\section{Conclusion}

This study reveals that the stylistic significance of Robert Coover's complex sentences exists. This stylistic significance seems pertinent in relating form to function in Coover'sChicago Cryptogram. The much density of information and details per sentence makes Coover use complex sentences profusely throughout the story and this is his stylistic marker. In this case, subordination has a great number of clauses than coordination because the supporting and modifying ideas are more than the principal ones. Also, the sentences with the highest number of clauses are always related to the presentation either of necessary background information about the characters or description of key actions within the general framework of narration.

\section{References}

Coover, R. (2005). “ Chicago Cryptogram.” In Coover (ed.). AChildAgain. New York: McSweeney, pp. 51-63.

Gracia, A. (2002). The Mexicans Americans. New York: Greenwood Publishing Group.

Leech, G. and M. Short (1981). Style in Fiction. London: Longman.

Quirk, R. and S. Greenbaum (1973). A University Grammar of English. London: Longman.

Quirk, R., S. Greenbaum, G. Leech and J. Svartvik (1985). A Comprehensive

Grammar of the English Language.London: Longman.

Strumph, M. and A. Douglas (1999). The Grammar Bible. Los Angles: Quality Books Inc.

Turner, G. (1973). Stylistics. Harmondworth: Penguin Books Ltd.

Wright, L. and J. Hope (1996). Stylistics: A Practical Course Book. London: Routledge.

الجمل المعقدة هي السمات النحوية التي يستعملها كتاب الادب, بما في ذلك القصة القصيرة, كوسيلة لتحقيق

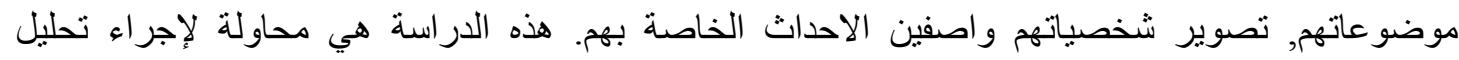

لاستعمالات روبرت كوفر الفعالة اسلوبيا للجمل المعقدة في قصته القصيرة نبتة شيكاغو اللازهرية من مجمو عنه 


\section{University of Thi-Qar Journal Vol.10 No.1 Mar 2015}

Web Site: https://jutq.utq.edu.iq/index.php/main Email: journal@jutq.utq.edu.iq

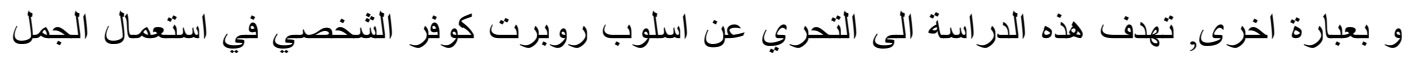

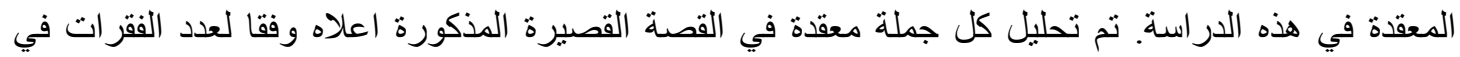

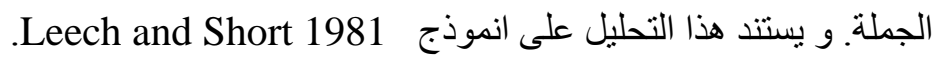

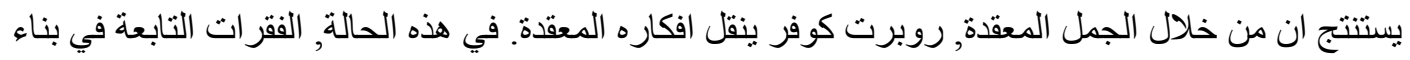

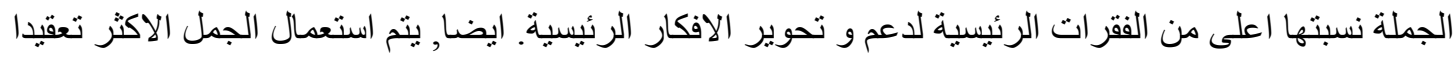

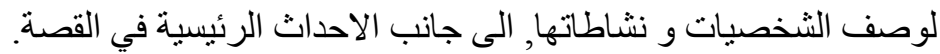

